\title{
Superacids and Their Derivatives. $X$. Mechanistic Studies of Selective Cyclodimerization of Ethylene Oxide by Superacid Ester Catalysts
}

\author{
Shiro Kobayashi, Kenji Morikawa, and Takeo SaEgusa \\ Department of Synthetic Chemistry, Faculty of Engineering, \\ Kyoto University, Kyoto 606, Japan.
}

(Received September 30, 1978)

\begin{abstract}
Cyclodimerization of ethylene oxide (EO) to 1,4-dioxane (DON) by using superacids and their derivatives as catalysts was examined. Results are discussed on the basis of the catalyst nature. Kinetic analyses were performed by monitoring the reaction with ${ }^{1} \mathrm{H}$ - and ${ }^{19} \mathrm{~F}-\mathrm{NMR}$ spectroscopy. The rate constant of initiation $\left(k_{i}\right)$ and the apparent one of propagation $\left(k_{\mathrm{p}(\mathrm{ap})}\right)$ were obtained. The rate constant of propagation due to ester species $\left(k_{\mathrm{p}(\mathrm{e})}\right)$ was evaluated from a model reaction. The EO consumption rate could not be explained by assuming only ester active species. It was found that in addition to the ester species oxonium active species was responsible for the EO consumption, even if they were not detected by ${ }^{19} \mathrm{~F}-\mathrm{NMR}$. A general scheme is presented and discussed. A model reaction of a "back-biting" process was also studied.
\end{abstract}

KEY WORDS Ethylene Oxide / 1,4-Dioxane / Cyclodimerization / Superacid Ester / Model Reaction /

In a previous communication ${ }^{1}$ we reported the selective cyclodimerization of ethylene oxide (EO) to 1,4-dioxane (DON) catalyzed by superacids, their esters, and their anhydrides. This finding afforded a convenient synthetic method of DON from EO. Recently, cyclooligomerizations of hetero cyclic monomers have been an interesting topic in the field of ring-opening polymerization. ${ }^{2}$ Since the chemistry of crown ethers has been developed, ${ }^{3}$ various crown ethers have been prepared by cyclooligomerizations of cyclic ether monomers, e.g., EO ${ }^{4}$ substituted oxiranes, ${ }^{5}$ oxetane, ${ }^{6}$ and tetrahydrofuran. ${ }^{7}$ Among these cyclooligomerizations, the cyclodimerization of EO to DON is one of the most selective and readily-occurring reactions. ${ }^{1,2}$ The present paper is focused on the mechanistic studies of cyclodimerization of EO to DON catalyzed by superacid esters, mainly from the standpoints of kinetics and model reactions.

\section{EXPERIMENTAL}

\section{Reagents}

EO, a commercial reagent, was used by distilling it into a reaction tube at $-78^{\circ} \mathrm{C}$. Trifluoromethanesulfonic $\left(\mathrm{CF}_{3} \mathrm{SO}_{3} \mathrm{H}, \mathrm{TfOH}\right)$, chlorosulfonic $\left(\mathrm{ClSO}_{3} \mathrm{H}\right)$, and perchloric $\left(\mathrm{HClO}_{4}\right)$ acids were commercial reagents and were used without further purification. Fluorosulfonic acid $\left(\mathrm{FSO}_{3} \mathrm{H}\right)$ was prepared from fuming $\mathrm{H}_{2} \mathrm{SO}_{4}$ and hydrogen fluoride which was obtained from Daikin Kogyo Co. (Osaka), bp $80^{\circ} \mathrm{C}$ $(45 \mathrm{mmHg})$ (lit. $\left.{ }^{8} 162.7^{\circ} \mathrm{C}\right)$. Superacid esters were prepared as previously reported. ${ }^{9-11}$ Trifluoromethanesulfonic anhydride $\left(\mathrm{Tf}_{2} \mathrm{O}\right)$ was obtained by dehydration of $\mathrm{TfOH}$ with $\mathrm{P}_{2} \mathrm{O}_{5}$, bp $83-84^{\circ} \mathrm{C}$ (lit. ${ }^{12}$ $\left.84^{\circ} \mathrm{C}\right)$.

Model compounds of ester type active species such as 2-ethoxyethyl trifluoromethanesulfonate were prepared by the following reactions of $\mathrm{Tf}_{2} \mathrm{O}$ with the corresponding alcohols in $\mathrm{CCl}_{4}$ at $0^{\circ} \mathrm{C}$ in the presence of pyridine.

$$
\mathrm{ROH}+\mathrm{Tf}_{2} \mathrm{O} \stackrel{\text { Pyridine }}{\longrightarrow} \mathrm{ROTf}+\mathrm{PyH}^{+} \cdot \mathrm{OTf}^{-}
$$

Pyridinium salt formed an upper layer which was removed, and the residual $\mathrm{CCl}_{4}$ solution was concentrated and used directly. ${ }^{1} \mathrm{H}-$ and ${ }^{19} \mathrm{~F}-\mathrm{NMR}$ studies showed the production of ROTf without any impurities. 


\section{Cyclodimerization}

In almost all cases the reaction was carried out in a sealed NMR sample tube. A typical procedure (No. 2 in Table I) was as follows. Under nitrogen at $-78^{\circ} \mathrm{C}, 0.20 \mathrm{ml}(4.0 \mathrm{mmol})$ of $\mathrm{EO}$ was introduced into an NMR tube by distillation. To this, $0.20 \mathrm{~m} l$ of $\mathrm{CH}_{2} \mathrm{Cl}_{2}$ and $25 \mu l(0.20 \mathrm{mmol})$ of EtOTf was added by using a micro-syringe at the same temperature. Then the tube was sealed, well shaken at $0^{\circ} \mathrm{C}$ to make the mixture homogeneous, and kept at $35^{\circ} \mathrm{C}$. It was confirmed by ${ }^{1} \mathrm{H}$ NMR that EO was completely consumed after $28 \mathrm{~h}$. The tube was then opened and the reaction mixture was quenched by pouring it into $0.5 \mathrm{ml}$ of methanol containing $\mathrm{CH}_{3} \mathrm{ONa}(0.23 \mathrm{mmol})$ and chlorobenzene as an internal standard for the GC analysis. The quenched mixture was subjected to the GC analysis to determine the amount of DON.

For the kinetic analysis, the reaction was carried out also in an NMR sample tube and monitored with ${ }^{1} \mathrm{H}$ - and/or ${ }^{19} \mathrm{~F}-\mathrm{NMR}$ spectroscopy.

The GC analysis was performed on a Shimadzu gas chromatograph model GC-6A by using a silicone column.

${ }^{1} \mathrm{H}$ - and ${ }^{19} \mathrm{~F}-\mathrm{NMR}$ spectra were recorded on a Hitachi R-20B NMR spectrometer.

\section{RESULTS AND DISCUSSION}

\section{Cyclodimerization of $E O$}

Results of cyclodimerization of EO under various reaction conditions are summarized in Table I. In addition to DON, small quantities of 2-methyl-1,3dioxolane (less than several percents for DON) and of ethylene and diethylene glycol derivatives were formed in all systems. Higher linear and cyclic oligomers were detected, but their amounts were

Table I. Cyclodimerization of EO to DON under various reaction conditions ${ }^{\mathrm{a}}$

\begin{tabular}{|c|c|c|c|c|c|c|c|}
\hline No. & Catalyst & $\mathrm{mol} \%$ for $\mathrm{EO}$ & Solvent & $\begin{array}{c}\text { Reaction } \\
\text { temp, } \\
{ }^{\circ} \mathrm{C}\end{array}$ & $\begin{array}{c}\text { Reaction } \\
\text { time, } \\
\mathrm{h}\end{array}$ & $\begin{array}{c}\text { Conversion } \\
\text { of } \mathrm{EO}, \\
\%\end{array}$ & $\begin{array}{c}\text { Yield } \\
\text { of } \mathrm{DON}, \\
\%\end{array}$ \\
\hline 1 & EtOTf & 5.0 & & 35 & 10 & 100 & 92 \\
\hline 2 & " & 5.0 & $\mathrm{CH}_{2} \mathrm{Cl}_{2}$ & 35 & 28 & 100 & 89 \\
\hline 3 & $" \prime$ & 5.0 & $\mathrm{CH}_{3} \mathrm{NO}_{2}$ & 35 & 1.3 & 100 & 90 \\
\hline 4 & " & 5.0 & $\mathrm{PhNO}_{2}$ & 35 & 3 & 100 & 91 \\
\hline 5 & MeOTf & 1.1 & & 35 & 16.5 & 100 & 95 \\
\hline 6 & " & 1.1 & $\mathrm{CH}_{3} \mathrm{NO}_{2}$ & 35 & 4 & 100 & 96 \\
\hline 7 & " & 5.0 & $\mathrm{CH}_{3} \mathrm{NO}_{2}$ & 10 & 14.5 & 100 & 88 \\
\hline 8 & " & 5.0 & $\mathrm{CH}_{2} \mathrm{Cl}_{2}$ & 35 & 13 & 100 & 88 \\
\hline 9 & $\mathrm{EtOSO}_{2} \mathrm{~F}$ & 5.1 & & 35 & 13 & 100 & 90 \\
\hline 10 & " & 5.1 & $\mathrm{CH}_{2} \mathrm{Cl}_{2}$ & 35 & 17 & 100 & 82 \\
\hline 11 & $\mathrm{MeOSO}_{2} \mathrm{Cl}$ & 5.1 & & 40 & 4 & 30 & 6 \\
\hline 12 & $\mathrm{TfOH}$ & 2.0 & & 20 & 13.5 & 100 & 80 \\
\hline 13 & $\mathrm{FSO}_{3} \mathrm{H}$ & 2.5 & & 20 & 17.5 & 100 & 65 \\
\hline 14 & $\mathrm{ClSO}_{3} \mathrm{H}$ & 4.7 & $\mathrm{CH}_{2} \mathrm{Cl}_{2}$ & 20 & 4 & 20 & 3 \\
\hline 15 & $\mathrm{TfOH} \cdot \mathrm{H}_{2} \mathrm{O}$ & 2.0 & & 20 & 5 & 100 & 30 \\
\hline 16 & $70 \%$ aq $\mathrm{HClO}_{4}$ & 2.1 & & 20 & 5 & 100 & 20 \\
\hline 17 & AgOTf + concd $\cdot \mathrm{H}_{2} \mathrm{SO}_{4}$ & 3.3 & & 20 & 27 & 100 & 35 \\
\hline 18 & $\mathrm{NaOTn}{ }^{\mathrm{b}}+$ concd $\cdot \mathrm{H}_{2} \mathrm{SO}_{4}$ & 2.9 & & 20 & 41 & 65 & 10 \\
\hline 19 & $\mathrm{Tf}_{2} \mathrm{O}$ & 4.6 & $\mathrm{CH}_{2} \mathrm{Cl}_{2}$ & 40 & 10 & 100 & 91 \\
\hline 20 & $95 \%$ aq $\mathrm{H}_{2} \mathrm{SO}_{4}$ & 2.0 & & 20 & 5 & 16 & 0 \\
\hline 21 & $\mathrm{MeOTs}^{\mathrm{c}}$ & 4.7 & $\mathrm{PhNO}_{2}$ & 40 & 10 & 0 & 0 \\
\hline 22 & $\mathrm{Me}_{2} \mathrm{SO}_{4}$ & 5.2 & $\mathrm{PhNO}_{2}$ & 40 & 7 & 0 & 0 \\
\hline 23 & $\mathrm{Et}_{3} \mathrm{O}^{+} \mathrm{BF}_{4}^{-}$ & 4.0 & $\mathrm{CH}_{2} \mathrm{Cl}_{2}$ & 35 & $<0.1^{\mathrm{d}}$ & 100 & 27 \\
\hline 24 & & 1.6 & $\mathrm{CH}_{2} \mathrm{Cl}_{2}$ & 0 & 9 & 100 & 90 \\
\hline
\end{tabular}

a The charged EO was $8.0 \mathrm{mmol}$ when bulk and $4.0 \mathrm{mmol}$ in $0.20 \mathrm{~mol}$ of solvent when in solution reaction.

b Sodium 2,4,6-trinitrobenzenesulfonate. ${ }^{13}$

c Methyl $p$-toluenesulfonate.

d An exothermal reaction took place and EO was consumed spontaneously. 
negligibly small, so their quantitative analyses were not made in this study.

The following five features can be important, depending on the nature of the catalysts.

(i) Esters of stable superacids such as EtOTf, MeOTf, and $\mathrm{EtOSO}_{2} \mathrm{~F}$ (No. 1-10) and a stable superacid anhydride of $\mathrm{Tf}_{2} \mathrm{O}$ (No. 19) effectively consumed EO and selectively gave DON. These systems did not contain "acidic protons," and therefore favored the production of DON from EO.

(ii) Superacids (No. 12, 13, 15, and 16) and analogous catalysts which generate superacids in situ (No. 17 and 18) showed high activities for the EO consumption but produced DON less selectively. The products other than DON were mainly poly-EO. These observations are consistent with those found by Worsfold and Eastham, ${ }^{4 a}$ i.e., the amount of DON from EO catalyzed by $\mathrm{BF}_{3}$ was a function of the amount of "protons" present in the system. The larger the amount of protons is, the less the extent of the DON production becomes.

(iii) The reactions with $\mathrm{MeOSO}_{2} \mathrm{Cl}$ (No. 11) and $\mathrm{ClSO}_{3} \mathrm{H}$ (No. 14) systems ceased at low conversions of EO and yielded only a small amount of DON. This phenomenon is due to the lower stability of the $\mathrm{ClSO}_{3}$ group compared with the TfO or $\mathrm{FSO}_{3}$ group, ${ }^{14}$ i.e., the less stable (more reactive) $\mathrm{Cl}-\mathrm{S}$ bond is cleaved readily to give an alkyl chloride, ${ }^{14}$ e.g.,

$$
\stackrel{\sim \mathrm{OCH}_{2} \mathrm{CH}_{2} \mathrm{OSO}_{2} \mathrm{Cl} \longrightarrow}{\sim \mathrm{OCH}_{2} \mathrm{CH}_{2} \mathrm{Cl}+\mathrm{SO}_{3}}
$$

and/or to give, for example, a dialkyl sulfate when a reactive proton is involved in the system, such as

$$
\stackrel{\sim \mathrm{OCH}_{2} \mathrm{CH}_{2} \mathrm{OSO}_{2} \mathrm{Cl}+\mathrm{HOCH}_{2} \sim \sim \longrightarrow}{\sim \mathrm{OCH}_{2} \mathrm{CH}_{2} \mathrm{OSO}_{2} \mathrm{OCH}_{2} \sim \sim+\mathrm{HCl}}
$$

All these side reactions brought about the termination of the EO consuption.

(iv) A strong acid (No. 20) and two strong acid esters (No. 21 and 22) did not produce DON at all. This phenomenon constitutes a sharp contrast to the results of superacids and their ester catalysts. The acidity function of $H_{0}=-12$ is considered as the border-line acid strength between superacids and strong acids. ${ }^{15}$

(v) The oxonium salt (No. 23 and 24) produced DON in high yields when the reaction was carried out under anhydrous conditions at lower temperatures.

\section{Mechanistic and Kinetic Studies}

Mechanistic studies of the EO cyclodimerization were carried out from the kinetic viewpoint. The results were related to the mechanism of the other cyclic ether polymerizations by superacids and their derivatives. ${ }^{9-11,16,17}$ Superacid esters were used as catalysts, since such catalysts provided less complicated systems for the kinetic analysis. ${ }^{9}$

The EtOTf catalyzed cyclodimerization was monitored by ${ }^{1} \mathrm{H}-\mathrm{NMR}$ spectrometry. Two spectra and signal assignments were shown in our previous paper. ${ }^{1}{ }^{19} \mathrm{~F}-\mathrm{NMR}$ spectrum of the same system showed a sharp singlet at $\delta+2.98^{18}$ (relative to external $\mathrm{CF}_{3} \mathrm{CO}_{2} \mathrm{H}$ ) assignable to ester type $\sim \mathrm{CH}_{2} \mathrm{OTf}$, in addition to a peak at $\delta+2.62$ due to EtOTf. From these observations the consumptions of EO and EtOTf could be followed (Figure 1). It should be noted that EtOTf was not consumed completely, but several percents of EtOTf remained even at the later stage of the reaction, probably due to equilibration. Furthermore, oxonium species were detected by ${ }^{19} \mathrm{~F}-\mathrm{NMR}$ spectroscopy at the later stage of reaction when polar solvents were used.

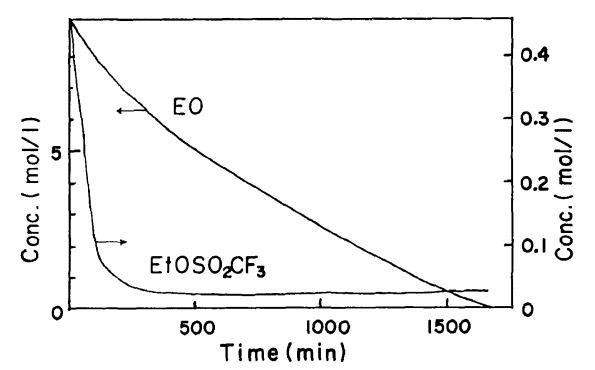

Figure 1. Concentrations of EO and EtOTf with respect to reaction time at $35^{\circ} \mathrm{C}$ in $\mathrm{CH}_{2} \mathrm{Cl}_{2}:[\mathrm{EO}]_{0}=9.2$ $\mathrm{mol} / l ;[\text { EtOTf }]_{0}=0.46 \mathrm{~mol} / l$.

Kinetic analyses were first made by simply considering the following elementary reactions catalyzed with ROTf.

Initiation

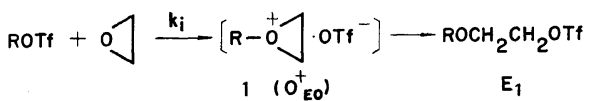

Propagation

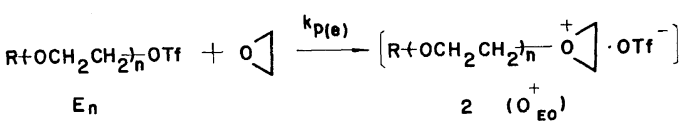




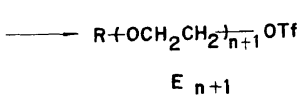

Cyclodimerization

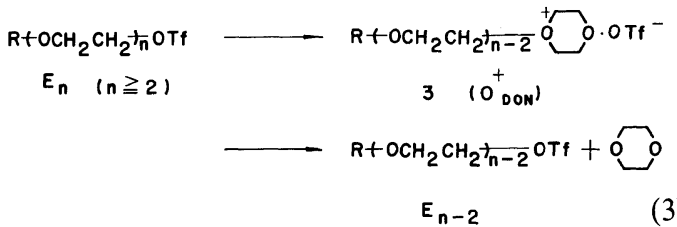

(2) of propagating species. The integrated forms of eq 4 and 5 are

$$
\ln [\mathrm{I}]_{0} /[\mathrm{I}]_{t}=k_{i} \int_{0}^{t}[\mathrm{EO}] \mathrm{d} t
$$

and

$$
\ln [\mathrm{EO}]_{t_{1}} /[\mathrm{EO}]_{t_{2}}=k_{i} \int_{t_{1}}^{t_{2}}[\mathrm{I}] \mathrm{d} t+k_{\mathrm{plap})} \int_{t_{1}}^{t_{2}}\left[\mathrm{P}^{*}\right] \mathrm{d} t
$$

According to these reactions, the following rate equations are derived. At a very early stage of reaction the rate equation of initiation is given by

$$
-\mathrm{d}[\mathrm{I}] / \mathrm{d} t=k_{i}[\mathrm{I}][\mathrm{EO}]
$$

where $k_{i}$ and [I] are the initiation rate constant and the concentration of the initiator (catalyst). The general form of the EO consumption rate is

$$
-\mathrm{d}[\mathrm{EO}] / \mathrm{d} t=k_{i}[\mathrm{I}][\mathrm{EO}]+k_{\mathrm{p}(\mathrm{ap})}\left[\mathrm{P}^{*}\right][\mathrm{EO}]
$$

where $k_{\mathrm{p}(\mathrm{ap})}$ is the apparent rate constant of propagation and $\left[\mathrm{P}^{*}\right]$ represents the total concentration
Based on eq 6 and 7, kinetic analyses were carried out with three superacid ester catalysts (Table II). The $k_{i}$ and $k_{\mathrm{p}(\mathrm{ap})}$ values increased with the increase of the solvent polarity. It is likely that EO is consumed by reactions not only with ester species such as the catalyst, $E_{1}$, and $E_{n}$ but also with oxonium species such as $\mathbf{1}, \mathbf{2}$, and $\mathbf{3}$ in eq $1-3$, because oxonium species were actually detected by ${ }^{19} \mathrm{~F}$ NMR during the reaction.

\begin{tabular}{|c|c|c|c|c|c|c|c|c|c|}
\hline \multirow[t]{2}{*}{ No. } & \multirow[t]{2}{*}{ Catalyst } & \multirow{2}{*}{$\begin{array}{c}\text { Reaction } \\
\text { condition }^{\mathrm{a}}\end{array}$} & \multirow[t]{2}{*}{ Solvent } & \multirow{2}{*}{$\begin{array}{c}{\left[\mathrm{O}^{+}\right]{ }^{\mathrm{b}}} \\
\%\end{array}$} & $k_{i}$ & $k_{\mathrm{p}(\mathrm{ap})}$ & $k_{\mathrm{p}(\mathrm{e})}{ }^{\mathrm{c}}$ & \multicolumn{2}{|c|}{$\begin{array}{l}\text { Fraction of EO } \\
\text { consumption, } \%\end{array}$} \\
\hline & & & & & \multicolumn{3}{|c|}{$\left(\times 10^{5} \mathrm{l} / \mathrm{mol} \cdot \mathrm{s}\right)$} & $\mathrm{E}$ & $\mathrm{O}^{+}$ \\
\hline 25 & EtOTf & A & $\mathrm{CCl}_{4}$ & nd & 2.8 & 2.5 & 0.30 & 19 & 81 \\
\hline 26 & " & $\mathrm{A}$ & $\mathrm{C}_{6} \mathrm{H}_{6}$ & nd & 2.8 & 2.6 & 0.67 & 35 & 65 \\
\hline 27 & "' & A & $\mathrm{CHCl}_{3}$ & nd & 2.9 & 3.2 & 0.80 & 28 & 72 \\
\hline 28 & " & $\mathrm{A}$ & $\mathrm{CH}_{2} \mathrm{Cl}_{2}$ & nd & 4.1 & 3.3 & 0.95 & 34 & 66 \\
\hline 29 & " & A & DON & nd & 7.1 & 4.3 & & & \\
\hline 30 & " & B & none & 1 & 8.1 & 6.8 & 1.9 & 33 & 67 \\
\hline 31 & " & A & $\mathrm{PhNO}_{2}$ & 3 & 11 & 30 & 3.5 & 14 & 86 \\
\hline 32 & " & A & $\mathrm{CH}_{3} \mathrm{NO}_{2}$ & 10 & 24 & 53 & 4.4 & 10 & 90 \\
\hline 33 & MeOTf & A & $\mathrm{CH}_{2} \mathrm{Cl}_{2}$ & nd & 5.6 & 2.9 & & & \\
\hline 34 & " & B & none & 1 & 11 & 7.9 & & & \\
\hline 35 & " & A & $\mathrm{PhNO}_{2}$ & 2 & 14 & 19 & & & \\
\hline 36 & " & $\mathrm{C}$ & $\mathrm{CCl}_{4}$ & nd & 2.3 & 2.0 & & & \\
\hline 37 & " & $\mathrm{C}$ & $\mathrm{CH}_{2} \mathrm{Cl}_{2}$ & nd & 3.8 & 6.2 & & & \\
\hline 38 & " & $\mathrm{C}$ & $\mathrm{PhNO}_{2}$ & 1 & 15 & 30 & & & \\
\hline 39 & $\mathrm{EtOSO}_{2} \mathrm{~F}$ & A & $\mathrm{CH}_{2} \mathrm{Cl}_{2}$ & nd & 3.0 & 4.1 & & & \\
\hline 40 & " & B & none & nd & 4.8 & 4.2 & & & \\
\hline 41 & $" \prime$ & A & $\mathrm{PhNO}_{2}$ & nd & 6.0 & 14 & & & \\
\hline 42 & "' & A & $\mathrm{CH}_{3} \mathrm{NO}_{2}$ & 4 & 11 & 33 & & & \\
\hline
\end{tabular}

In order to follow the change of the respective species in more detail, a large amount of catalyst

Table II. Kinetic data of the cyclodimerization of EO catalyzed by superacid esters at $35^{\circ} \mathrm{C}$

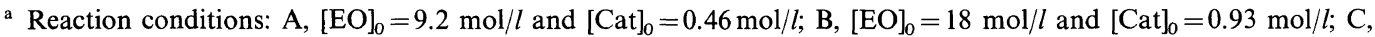
$[\mathrm{EO}]_{0}=4.5 \mathrm{~mol} / l$ and $[\mathrm{Cat}]_{0}=2.0 \mathrm{~mol}$.

b Oxonium fraction (\%) toward [Cat $]_{0}$ observed at the later stage of reaction; nd indicares no detection by ${ }^{19} \mathrm{~F}$ NMR.

c Reaction conditions: $[E O]_{0}=9.2 \mathrm{~mol} / l$ and $\left[\mathrm{E}_{1}\right]=0.5 \mathrm{~mol} / l$, except $\mathrm{No}$. 30 , where $[\mathrm{EO}]=18 \mathrm{~mol} / l$ and $\left[\mathrm{E}_{1}\right]=0.8 \mathrm{~mol} / l$. 


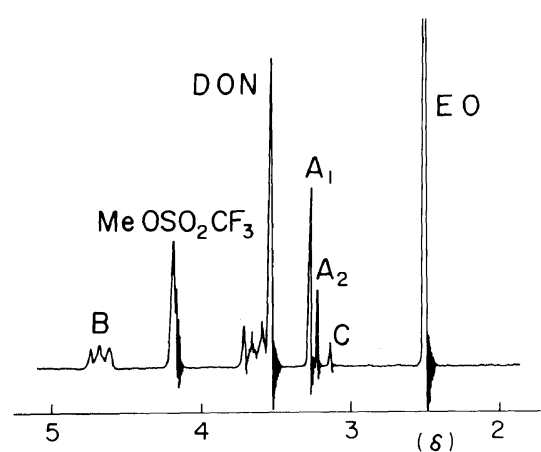

Figure 2. ${ }^{1} \mathrm{H}-\mathrm{NMR}$ spectrum of the cyclodimerization system with MeOTf catalyst in $\mathrm{PhNO}_{2}$ at $35^{\circ} \mathrm{C}$ after $20 \mathrm{~min}:[\mathrm{EO}]_{0}=4.5 \mathrm{~mol} / l ;[\mathrm{MeOTf}]_{0}=2.0 \mathrm{~mol} / l$.

(MeOTf, $44 \mathrm{~mol} \%$ for EO) was employed and the reaction was monitored. Figure 2 shows the ${ }^{1} \mathrm{H}$ NMR spectrum of the reaction system. The triplet peak $\mathrm{B}$ at $\delta 4.62$ is reasonably assigned to the ester type methylene $\sim \mathrm{CH}_{2} \mathrm{OTf}$. In the methoxy signal region three singlets were observed: $A_{1}$ at $\delta 3.28, A_{2}$ at $\delta 3.23$, and a small peak $\mathrm{C}$ at $\delta 3.14$. For the peak assignments the following authentic esters were prepared.

$$
\begin{gathered}
\left.\mathrm{CH}_{3}+\mathrm{OCH}_{2} \mathrm{CH}_{2}\right)_{n} \mathrm{OTf} \\
\mathrm{E}_{n}(n=1,2,3)
\end{gathered}
$$

The methoxy signals appeared at the following position of $\mathrm{CCl}_{4}$ solution: $\mathrm{E}_{1}$ and $\delta 3.30, \mathrm{E}_{2}$ at $\delta 3.23$, and $\mathrm{E}_{3}$ at $\delta$ 3.22. From these data, peak $A_{1}$ was assigned to the methoxy signal of $\mathrm{E}_{1}$ species and peak $A_{2}$ was reasonably ascribed to $\mathrm{E}_{n}(n \geqq 2)$ species, since the methoxy signals of $\mathrm{E}_{n}(n \geqq 3)$ probably appear at the same position as that of $E_{2}$. Small peak $\mathrm{C}$, therefore, is due to a side product. According to the above observations, the concentration changes of species derived from EO and from catalyst were followed as shown in Figures 3 and 4, respectively.

Under the above reaction conditions, $70 \%$ of the charged EO converted to DON when EO was completely consumed. The remaining EO component was converted mainly to the superacid ester of $E_{1}$ and partly to $E_{n} ; E_{2}$ probably is the main fraction among $\mathrm{E}_{n}(n \geqq 2)$. The amount of MeOTf became constant during the reaction, indicating the occurrence of reaction (3) such as $\mathrm{E}_{2} \rightarrow \mathrm{DON}+\mathrm{E}_{0}$ (=catalyst). The $k_{i}$ and $k_{\mathrm{p}(\mathrm{ap})}$ values were also calculated (No. 36-38 in Table II).

The largest quantity of propagating species (active

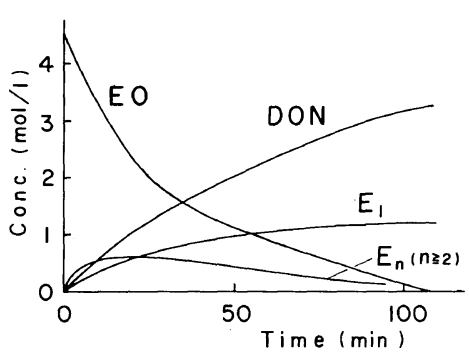

Figure 3. The concentration-time relationships of species derived from $\mathrm{EO}$ in $\mathrm{PhNO}_{2}$ at $35^{\circ} \mathrm{C}$ : $[\mathrm{EO}]_{0}=4.5$ $\mathrm{mol} / l ;[\mathrm{MeOTf}]_{0}=2.0 \mathrm{~mol} / l$. The concentrations are given based on the EO molar unit.

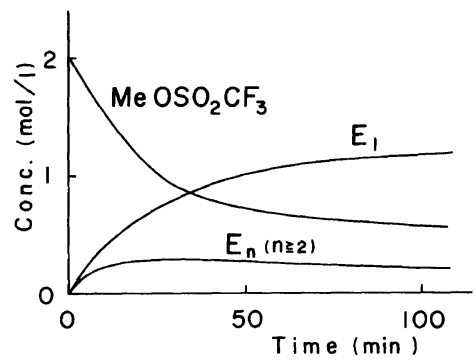

Figure 4. The concentration-time relationships of species containing $\mathrm{TfO}$ group in $\mathrm{PhNO}_{2}$ at $35^{\circ} \mathrm{C}:[\mathrm{EO}]_{0}=4.5$ $\mathrm{mol} / l ;[\mathrm{MeOTf}]_{0}=2.0 \mathrm{~mol} / l$.

sites) is $E_{1}$, as shown in Figure 4. It becomes important, therefore, to know the reactivity of $E_{1}$. The following reaction was carried out in order to determine the rate constant of $k_{\mathrm{E}_{1}}$.

$$
\begin{aligned}
& \left.\mathrm{EtOCH}_{2} \mathrm{CH}_{2} \mathrm{OTf}+\mathrm{O}\right] \frac{\mathrm{k}_{\mathrm{E}_{1}}}{\text { slow }}\left[\mathrm{EtOCH}_{2} \mathrm{CH}_{2}-\stackrel{+}{0} \text { J. OTf }{ }^{-}\right] \\
& E_{1} \\
& \begin{array}{c}
\text { fost }-\mathrm{EtOCH}_{2} \mathrm{CH}_{2} \mathrm{OCH}_{2} \mathrm{CH}_{2} \mathrm{OTf} \\
\mathrm{E}_{2}
\end{array}
\end{aligned}
$$

Reaction (8) is a model reaction of propagating reaction (2), where a model of the smallest propagating species $\mathrm{E}_{1}$ is used. The $k_{\mathrm{E}_{1}}$ values were obtained by a similar kinetic analysis for reaction (1). Now, it is reasonable to assume that the reactivity of $E_{1}$ toward EO could be equal to that of $\mathrm{E}_{n}(n \geqq 2)$, i.e., $k_{\mathrm{E}_{1}}=k_{\mathrm{p}(\mathrm{e})}$. Kinetic analyses of reaction (8) were carried out in seven different solvents and these $k_{\text {p(e) }}$ values are listed in Table II. These results show that $E_{1}$ is about 3-10 times less reactive toward EO than 


\section{EtOTf.}

An attempt was made to evaluate how much EO was actually consumed by ester and ionic type active species. The following relationship is gerenally given $^{10,11}$

$$
k_{\mathrm{p}(\mathrm{ap})} \int_{t_{1}}^{t_{2}}\left[\mathrm{P}^{*}\right] \mathrm{d} t=k_{\mathrm{p}(\mathrm{e})} \int_{t_{1}}^{t_{2}}\left[\mathrm{E}_{n}\right] \mathrm{d} t+k_{\mathrm{p}(i)} \int_{t_{1}}^{t_{2}}\left[\mathrm{O}^{+}\right] \mathrm{d} t
$$

where $k_{\mathrm{p}(i)}$ denotes the rate constant of propagation due to ionic species and $\left[\mathrm{O}^{+}\right]$is the concentration of ionic (oxonium) species. From eq 7 and 9 the amount of EO consumed by ester type active species is given by

$$
k_{i} \int_{t_{1}}^{t_{2}}[\mathrm{I}] \mathrm{d} t+k_{\mathrm{p}(\mathrm{e})} \int_{t_{1}}^{t_{2}}\left[\mathrm{E}_{n}\right] \mathrm{d} t
$$

The time when the catalyst concentration became constant in Figure 1 was taken as $t_{1}$ for the analysis and then plots of value (10) vs. $\ln [\mathrm{EO}]_{t_{1}} /[\mathrm{EO}]_{t_{2}}$ were made at several points of time. The plots gave a straight line, whose slope represents the fraction of the EO consumption due to ester type active species. The fraction of EO consumption due to oxonium active species is, of course, unity minus that due to ester active species. These data are also included in the last two columns in Table II. It should be noted that EO was actually consumed by reactions with oxonium ions rather than ester species, even if oxonium ion species were not directly detected by ${ }^{19} \mathrm{~F}$ NMR (No. 25-28). In the systems where oxonium species were observed (No. 30-32), $67-90 \%$ of EO was consumed via its reactions with oxonium ions.

These results suggest, as already mentioned above, that very unstable yet very reactive EO oxonium species such as $\mathbf{1}$ and $\mathbf{2}$ as well as oxonium species of DON such as 3 react quickly with EO. Since the oxonium of EO has never been directly observed, ${ }^{19}$ ? the oxonium species directly observed in the present study is probably that of DON.

The cyclodimerization shown by reaction (3) is the so-called "back-biting" process to liberate a thermodynamically stable DON. In fact, it was confirmed that model compounds of $E_{2}$ and $E_{3}$ yielded DON according to reactions (11) and (12).

$$
\underset{E_{2}}{\operatorname{Mo}_{2} \mathrm{OCH}_{2} \mathrm{CH}_{2} \mathrm{~T}_{2} \mathrm{OTf}}-\mathrm{moOTH}_{\mathrm{O}}+\mathrm{O}_{\mathrm{O}}^{\mathrm{O}}
$$

$$
\underset{E_{3}}{\mathrm{Me}_{3} \mathrm{OCH}_{2} \mathrm{CH}_{2} \mathrm{~T}_{3} \mathrm{OTf}} \underset{\mathrm{E}_{1}}{\mathrm{MeOCH} \mathrm{CH}_{2} \mathrm{OTf}}+\mathrm{O}^{\mathrm{O} O}
$$

The behavior of $E_{2}$ was examined in more detail. Species $\mathrm{E}_{2}$ was kept in $\mathrm{CCl}_{4}$ at $35^{\circ} \mathrm{C}$ and followed by ${ }^{1} \mathrm{H}$ - and ${ }^{19} \mathrm{~F}-\mathrm{NMR}$ spectroscopy. It was found that the following reaction (13) took place and finally reached equilibrium.

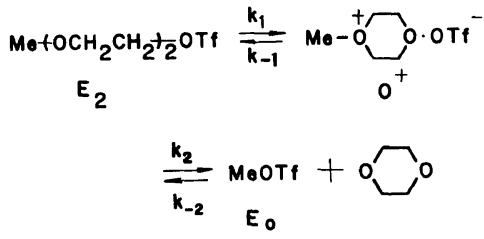

The time-conversion curves of three species are shown in Figure 5. The concentrations of these species of $\mathrm{E}_{2}, \mathrm{O}^{+}$, and $\mathrm{E}_{0}$ became constant after $1700 \mathrm{~min}$ and these values did not change after 3 days, indicating that the system already reached equilibration within $1700 \mathrm{~min}$.

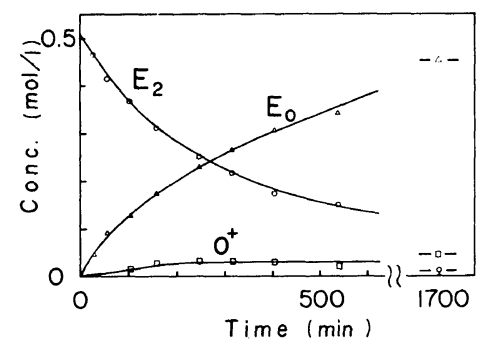

Figure 5. Time-conversion curves of three species of reaction (13) in $\mathrm{CCl}_{4}$ at $35^{\circ} \mathrm{C}:\left[\mathrm{E}_{2}\right]=0.51 \mathrm{~mol} / l$.

Kinetic analyses for the reaction (13) were made as follows. The rate constants of all steps (forward and back) are given in eq 13. The following relationships are derived

$$
\begin{aligned}
\frac{k_{-1}}{k_{1}} & =K_{1}=\frac{\left[\mathrm{E}_{2}\right]_{\mathrm{e}}}{\left[\mathrm{O}^{+}\right]_{\mathrm{e}}} \\
\frac{k_{-2}}{k_{2}} & =K_{2}=\frac{\left[\mathrm{O}^{+}\right]_{\mathrm{e}}}{\left[\mathrm{E}_{0}\right]_{\mathrm{e}}[\mathrm{DON}]_{\mathrm{e}}} \\
-\frac{\mathrm{d}\left[\mathrm{E}_{2}\right]}{\mathrm{d} t} & =k_{1}\left[\mathrm{E}_{2}\right]-k_{-1}\left[\mathrm{O}^{+}\right] \\
& =k_{1}\left[\mathrm{E}_{2}\right]-k_{1} K_{1}\left[\mathrm{O}^{+}\right]
\end{aligned}
$$




$$
\begin{aligned}
\frac{\mathrm{d}\left[\mathrm{E}_{0}\right]}{\mathrm{d} t}=\frac{d[\mathrm{DON}]}{\mathrm{d} t} & =k_{2}\left[\mathrm{O}^{+}\right]-k_{-2}\left[\mathrm{E}_{0}\right][\mathrm{DON}] \\
& =k_{2}\left[\mathrm{O}^{+}\right]-k_{2} K_{2}\left[\mathrm{E}_{0}\right]^{2}
\end{aligned}
$$

where the subscript e denotes the equilibrium, i.e., $\left[E_{2}\right]_{e}$ is the concentration of $E_{2}$ at equilibrium. Integration of eq 15 and 16 gave eq 17 and 18 , respectively.

$$
\begin{aligned}
& {\left[\mathrm{E}_{2}\right]_{t_{1}}-\left[\mathrm{E}_{2}\right]_{t_{2}}=k_{1}\left\{\int_{t_{1}}^{t_{2}}\left[\mathrm{E}_{2}\right] \mathrm{d} t-K_{1} \int_{t_{1}}^{t_{2}}\left[\mathrm{O}^{+}\right] \mathrm{d} t\right\}} \\
& {\left[\mathrm{E}_{0}\right]_{t_{2}}-\left[\mathrm{E}_{0}\right]_{t_{1}}=k_{2}\left\{\int_{t_{1}}^{t_{2}}\left[\mathrm{O}^{+}\right] \mathrm{d} t-K_{2} \int_{t_{1}}^{t_{2}}\left[\mathrm{E}_{0}\right]^{2} \mathrm{~d} t\right\}}
\end{aligned}
$$

From Figure 5, two equilibrium constants of eq 14 were obtained: $K_{1}=0.22$ and $K_{2}=0.22 \mathrm{l} / \mathrm{mol}$. With the use of these values, plots of eq 17 and 18 gave straight lines; these slopes gave $k_{1}=4.4 \times 10^{-5} \mathrm{~s}^{-1}$ and $k_{2}=7.8 \times 10^{-4} \mathrm{~s}^{-1}$ at $35^{\circ} \mathrm{C}$, respectively. The back-biting is slower than the DON liberation process. The formation of $\mathrm{MeOTf}=\mathrm{E}_{0}$ from $\mathrm{E}_{2}$ corresponds to the result indicated in Figure 1: that the catalyst never disappeared and its small portion remained constant at the stage of higher conversions. The rate constant of "back-biting" $\left(k_{1}\right)$ can be compared with that of the terahydrofuran polymerization system $\left(8.2 \times 10^{-3} \mathrm{~s}^{-1}\right.$ at $25^{\circ} \mathrm{C}$ in $\left.\mathrm{CCl}_{4}\right){ }^{20}$

From the above results, the following general scheme is considered to express the total reaction process. Processes (a) and (b) correspond to reaction (1) or (2). Process (a) is the only one in which EO is consumed by an ester type active species. Processes (f) and (e) are the back-biting reaction (cyclization) of $\mathrm{E}_{n}(n \geqq 2)$ and the liberation of DON as given by reaction (3), by which EO is not consumed. It was possible in this study to analyze these elementary processes quantitatively by the model reaction. The EO consumption could not reasonably be explained by simply considering ester type active species. It was postulated, therefore, that a very reactive yet unstable oxonium species such as the one derived from $\mathrm{EO}\left(\mathrm{O}_{\mathrm{EO}}^{+}\right)$was involved, even if it was not detected directly by ${ }^{19} \mathrm{~F}$ NMR, and was responsible for the EO consumption shown by process $(\mathrm{g})$. The species
$\mathrm{O}^{+}{ }_{E O}$ suffers quickly from the back-biting reaction to give an oxonium of DON $\left(\mathrm{O}^{+}{ }_{\text {DON }}\right)$ according to process (c). As an additional process, it is conceivable that $\mathrm{O}^{+}{ }_{\text {EO }}$ attacks EO to yield $\mathrm{O}^{+}{ }_{\text {DON }}$. The species $\mathrm{O}^{+}{ }_{\text {DON }}$, which could actually be detected, is also likely to react with $\mathrm{EO}$ as given by process (d). The rather complicated mechanism of the whole cyclodimerization is due to the involvement of $\mathrm{O}^{+}{ }_{\mathrm{EO}}$ and/or $\mathrm{O}^{+}{ }_{\text {DON }}$, the quantitative study of whose reactivity was difficult.

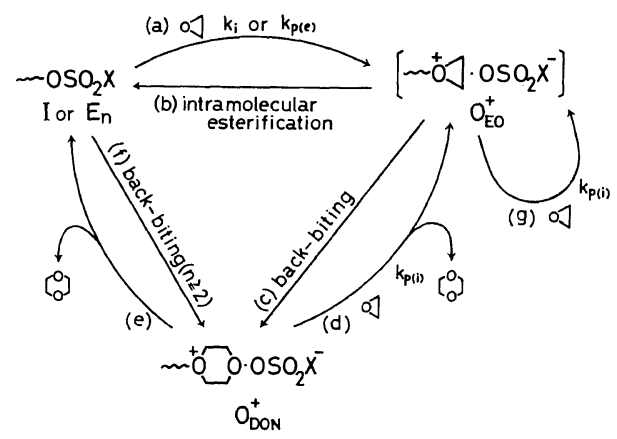

Scheme 1. General scheme of cyclodimerization of EO by superacid ester catalysts $\left(\mathrm{X}=\mathrm{CF}_{3}, \mathrm{~F}\right.$, etc.).

\section{REFERENCES}

1. S. Kobayashi, K. Morikawa, and T. Saegusa, Macromolecules, 8, 952 (1975).

2. For example, see E. J. Goethals, Adv. Polym. Sci., 23, 104 (1977).

3. (a) C. J. Pedersen, J. Am. Chem. Soc., 89, 2495, 7017 (1967); (b) C. J. Pedersen and H. K. Frensdorff, Angew. Chem. Int. Ed., 11, 16 (1972); (c) J. J. Christensen, D. T. Eatough, and R. M. Izatt, Chem. Rev., 74, 351 (1974); (d) D. J. Cram, R. C. Helgeson, L. R. Sousa, J. M. Timko, M. Newcomb, P. Moreau, F. de Jong, G. W. Gokel, G. H. Hoffman, L. A. Domeier, S. C. Teacock, K. Madan, and L. Kaplan, Pure Appl. Chem., 43, 327 (1975); (e) D. J. Cram and J. M. Cram, Science, 183, 803 (1974).

4. (a) D. J. Worsfold and A. M. Eastham, J. Am. Chem. Soc., 79, 897, 900 (1957); (b) G. A. Latremouille, G. T. Merrall, and A. M. Eastham, J. Am. Chem. Soc., 82, 120 (1960); (c) G. T. Merrall, G. A. Latremouille, and A. M. Eastham, Can. J. Chem., 38, 1967; (d) J. Dale and P. O. Kristiansen, Acta Chem. Scand., 26, 1471 (1972); (e) J. Dale, Tetrahedron, 30, 1683 (1974); (f) J. Dale, K. Daasvatn, and T. Grønneberg, Makromol. Chem., 178, 873 (1977).

5. (a) R. J. Katnik, and J. Schaefer, J. Org. Chem., 33, 
384 (1968); (b) R. J. Kern, J. Org. Chem., 33, 388 (1968); (c) S. G. Entelis and G. V. Korovina, Makromol. Chem., 175, 1253 (1974).

6. (a) J. B. Rose, J. Chem. Soc., 542, 546 (1956); (b) P. Dreyfuss and M. P. Dreyfuss, Polym. J., 8, 81 (1976).

7. G. Pruckmayr and T. K. Wu, Macromolecules, 11, 265 (1978).

8. R. J. Gillespie, Acc. Chem. Res., 1, 202 (1968).

9. S. Kobayashi, H. Danda, and T. Saegusa, Bull. Chem. Soc. Jpn., 46, 3214 (1973).

10. S. Kobayashi, H. Danda, and T. Saegusa, Macromolecules, 7, 415 (1974).

11. S. Kobayashi, K. Morikawa, and T. Saegusa, Macromolecules, 8, 386 (1975).

12. T. Gramstad and R. N. Haszeldine, J. Chem. Soc., 4069 (1957).

13. S. Kobayashi, T. Nakagawa, H. Danda, and T. Saegusa, Bull. Chem. Soc. Jpn., 47, 2706 (1974).
14. S. Kobayashi, T. Saegusa, and Y. Tanaka, Bull. Chem. Soc. Jpn., 46, 3220 (1973).

15. S. Kobayashi, Yuki Gosei Kagaku Kyokai Shi, 33, 861 (1975).

16. S. Kobayashi, N. Tsuchida, K. Morikawa, and T. Saegusa, Macromolecules, 8, 942 (1975).

17. S. Kobayashi, H. Danda, and T. Saegusa, Bull. Chem. Soc. Jpn., 47, 2699 (1974).

18. The positive sign denotes the down-field from the $\mathrm{CF}_{3} \mathrm{CO}_{2} \mathrm{H}$ standard and the negative sign corresponds to the up-field from the standard; Chem. Eng. News, 55 (31), 14 (1977).

19. (a) L. B. Lambert and D. H. Johnson, J. Am. Chem. Soc., 90, 1349 (1968); (b) G. A. Olah and P. J. Szilagyi, J. Org. Chem., 36, 1121 (1971).

20. K. Matyjaszewski, A. M. Buyle, and S. Penczek, $J$. Polym. Sci., Polym. Lett. Ed., 14, 125 (1976). 